\title{
Introduction to special issue: teacher agency and "Pedagogies of Hope" for bilingual learners (in a Brave New World)
}

\section{Deborah K. Palmer}

To cite this article: Deborah K. Palmer (2018): Introduction to special issue: teacher agency and "Pedagogies of Hope" for bilingual learners (in a Brave New World), International Multilingual Research Journal, DOI: 10.1080/19313152.2018.1474624

To link to this article: https://doi.org/10.1080/19313152.2018.1474624

Accepted author version posted online: 10

May 2018.

Submit your article to this journal

Q View related articles $\asymp$

View Crossmark data $₫$ 


\title{
Introduction to Special Issue: Teacher Agency and Pedagogies of Hope (in a Brave New World)
}

\author{
Deborah K. Palmer \\ University of Colorado Boulder, UCB-249, Boulder, CO 80301, 512-921-4336, \\ debpalmer@,colorado.edu
}

I am in search of hope. I suspect many who read this are too. For those of us who are or who work with immigrant, bilingual, and language/culture/race minoritized youth and their teachers, the current political climate has been an intellectual, emotional and physical challenge - more than usual. For this special issue, my intention was to seek out instantiations of hope that might sustain us in the continued struggle for justice in schools, especially for bilingual children. I have long found hope in classrooms, when children and teachers find spaces to assert their complex selves in the moments and spaces of school.

With this special issue, I have gathered a group of articles that attempt to chronicle, analyze, and draw energies from the empowered work of teachers who are bilingual (or multilingual), with learners who are bilingual. The articles draw on a range of theories in their analysis, and the authors approach their data with a range of methodologies. But across a spectrum of experiences, contexts, and stages in career, the teachers described in all of the articles in this issue are working hard to move forward with hope, embrace opportunities for agency, and engage their students in imagining more just futures for themselves and their worlds. 
Agency has been consistently framed as in tension with structure (Bourdieu, 1991; Foucault, 1995; Holland, Lachicotte, Skinner, \& Cain, 1998). Some theorists have appeared to favor a structural - and thus somewhat more deterministic - understanding of the ways in which humans shape their social worlds, leaving little room for individuals or groups of people to assert themselves against the realities of bureaucratic, governmental, or economic forces (Bowles \& Gintis, 2002; Foucault, 1995). In our present moment in the US, this has profound significance given the ways that the standards and high stakes testing movements and other neoliberal reforms have asserted structural forces in new and powerful ways into classrooms, schools and districts. Teachers feel the pressures of these structural influences; teachers working with bilingual children are particularly impacted, given the monoglossic, monolingual nature of standardization and neoliberal reforms.

On the other hand, Holland, et al. (1998) and others (e.g., Urrieta, 2009) assert the prominence of agency in the equation, in a "tension-ridden" (Bakhtin, 1998) dialogue with structure. Perhaps we need to move beyond this dichotomy, to embrace a dialectic tension in which structure and agency both exist, in conflict but interdependently, not to be envisioned as opposing ends of a linear spectrum but as entities sharing three-dimensional space: there exist both structure and agency in this world.

These five articles examine questions of teacher agency and hegemonic structure in schools. They come together under at least two common themes. First, they all explore the potential of teachers enacting agency to offer hopeful moments, spaces, and pedagogies in counter to subtractive, dominating, oppressive structures of power in schools. Second, they all assert that teachers' own cultural and linguistic identities and histories, and experiences of marginalization, are linked to their decisions to make their work about empowerment. 
Varghese and Snyder, looking at preservice dual language teachers in a monolingual, mainstream teacher preparation program, show us teachers at the very beginning of their careers, still working within the constraints of someone else's classroom, taking hold of assignments provided in their preparation program (despite its monoglossic orientation) to dialogue and develop the language and cultural competencies they require in order to be successful in dual language contexts. Drawing on a figured worlds framework (Holland, et al., 1998), they document moments in which especially their three Latinx participants draw on their own histories to navigate the complicated policy contexts - both state and local - and develop authentic engagement with their young students.

Venegas-Weber's exploration of the identities of practicing bilingual teachers in monoglossic dual language programs in the context of a midwestern new immigrant receiving state, draws on Anzaldúa's concept of nepantla. She finds that the teachers' bilingual identities belie their continuous positioning as monolinguals within the strict language separation of their dual language bilingual programs. The teachers she studied insisted upon humanizing relationships with their young bilingual students, articulating their need to model bilingual Latinx or Chicanx selves in the classroom.

Heiman and Yanes share the power and potential of Yanes' critical pedagogies of hope to counter the gentrification of her school community through a direct strike back. Her curriculum, pedagogical choices, and intentional engagement with parents and community demonstrate some possible ways to ensure that two-way dual language bilingual programs center the interests of the Latinx children and families they were designed to serve.

Colegrove and Zuñiga offer a unique perspective on agency: teachers' agency can emerge as a direct result of (and in relation with) their students' agency in the classroom. Letting go of 
control of classroom content and learning can allow for more learning, more love, and more joy. The teacher in their study, a multilingual immigrant from East Africa, did not hesitate to leverage her students' bilingualism for learning despite the fact that the program she worked within did not have bilingualism as a goal for students.

My own article, meanwhile, puts together the data from a large group of bilingual teachers - 53 in total - who embraced various moments of agency to become teacher leaders. They engaged as radical intellectuals, drew upon their own and their students' cultural and linguistic identities as strength, and created networks for support and hope to sustain their work through moments of challenge.

This group of articles is grounded in the hope-filled assumption that within educational spaces, there is always agency. In particular, I asked authors to articulate their understandings of teacher agency in bilingual spaces. The spaces that emerged across the articles range widely, and the teachers' identities also range widely. The narrative of struggle between (or amidst) structure and agency is ultimately a narrative of hope (Freire, 2000): a deep-seated belief in individuals and communities, moving out with critical consciousness to counter structural inequalities and oppression. In our particular socio-political moment, with negative, marginalizing, and disempowering rhetoric toward immigrant communities and communities of color increasingly normalized in the popular discourse, we need to better engage theories of agency, empowerment, and hope as we educate tomorrow's leaders.

Bakhtin, M. K. (1998). The Dialogic Imagination. Austin, Texas: University of Texas Press. Bourdieu, P. (1991). Language and Symbolic Power. Cambridge, MA: Harvard University Press. 
Bowles, S., \& Gintis, H. (2002). Schooling in Capitalist America Revisited. Sociology of Education, 75(1), 1-18. https://doi.org/10.2307/3090251

Foucault, M. (1995). Discipline and punish: the birth of the prison (2nd Vintage Books ed). New York: Vintage Books.

Freire, P. (2000). Pedagogy of the oppressed: 30th anniversary edition. New York: Continuum Publishing.

Holland, D., Lachicotte, W., Skinner, D., \& Cain, C. (1998). Identity and agency in cultural worlds. Cambridge, MA: Harvard University Press.

Urrieta, L. (2009). Working from within: Chicana and Chicano activist educators in whitestream schools. Tucson: University of Arizona Press. 